\title{
Pemetaan Akuifer Air Tanah Di Sekitar Candi Prambanan Kabupaten Sleman Daerah Istimewa Yogyakarta Dengan Menggunakan Metode Geolistrik Tahanan Jenis
}

\author{
Bayu A. Sadjaba*, As'aria, Adey Tanaumaa \\ aJurusan Fisika, FMIPA, Unsrat, Manado
}

KATA K UNCI

Akuifer air tanah

Geolistrik tahanan jenis

Software IP2WIN

Struktur lapisan tanah

\section{KEYW O R D}

Groundwater aquifer

Geoelectric resistivity

IP2WIN software

Soil layer structure

\section{A B S T R A K}

Telah dilakukan penelitian yang bertujuan untuk memetakan keberadaan akuifer air tanah di sekitar Candi Prambanan Kabupaten Sleman Daerah Istimewa Yogyakarta berdasarkan resistivitas batuan bawah permukaan hasil eksplorasi geofisika dengan metode geolistrik tahanan jenis. Penelitian dilakukan terhadap 31 titik sounding yang terbagi menjadi 6 lintasan. Setiap lintasan dibuat model struktur lapisan tanah di bawah permukaan. Air tanah yang tersimpan dalam akuifer dapat dieksplorasi dengan studi geofisika menggunakan metode geolistrik. Hasil eksplorasi diolah menggunakan software IP2WIN, menghasilkan model perlapisan bawah permukaan Bumi berdasarkan nilai resistivitasnya (2D) yang kemudian dioalah dengan software Surfer 8 untuk menghasilkan gambar tiga dimensi. Berdasarkan model struktur lapisan tanah di bawah permukaan ini diperoleh: a) lapisan akuifer air tanah dangkal dengan kedalaman antara ( 1 - 5 meter ) yang tersebar di Kecamatan Prambanan : Desa Bugisan (titik sounding 7) Desa Taji (titik sounding 14, 15, 23, 24, dan 31). b) lapisan akuifer air tanah dalam dengan kedalaman ( 25 - 100 meter ) yang tersebar di Kecamatan Prambanan : Desa Bugisan (titik sounding 1, 2, 3, 4, dan 5), Desa Tlogo (titik sounding 12, 16, dan 25). Di Kecamatan Kalasan : Desa Taman Martani (titik sounding 8, 9, 10, 17, 18, 19, 20, 21, 26, 27, 28, 29, dan 30.

A B S T R A C T

$A$ research has been done to map the aquifers around Prambanan Sleman in Yogyakarta based on the resistivity of ground subsurface as a result of the geophysics exploration by Geo-electric Resistivity Method. There were 31 sounding points used in this research and they were divided by 6 trajectories. Every trajectory was made a model of soil layers subsurface. The groundwater stored in a aquifer, and the aquifer condition of groundwater was explored with geophysics using geoelectric method. The exploration results were then processed using IP2WIN software that leads to a model of bedding the earth's subsurface based on the amount of resistivity (2D) then processed again using Surfer 8 Software to produce 3D image. The results showed that: a) layer of shallow groundwater aquifers to a depth of between (1-5 meters) spread in Prambanan: Bugisan village (sounding point 7) Taji Village (sounding points 14, 15, 23, 24, and 31). b) Layer aquifer groundwater in a depth of between (25-100 metres) spread in Prambanan: Bugisan village (sounding points 1, 2, 3, 4 and 5), Tlogo village (sounding points 12, 16 and 25). Kalasan village: Martani park (sounding points $8,9,10,17,18,19,20,21,26,27,28$, 29, and 30).

*Corresponding author: Jurusan Fisika FMIPA UNSRAT, Jl. Kampus Unsrat, Manado, Indonesia 95115; Email address: bayu_0705@yahoo.com Published by FMIPA UNSRAT (2012) 


\section{Pendahuluan}

Air yang kita gunakan sehari-hari telah menjalani siklus meteorik, yaitu telah melalui proses penguapan (precipitation) dari laut, danau, maupun sungai, lalu mengalami kondensasi di atmosfer, dan kemudian menjadi hujan yang turun ke permukaan bumi. Air hujan yang turun ke permukaan bumi tersebut ada yang langsung mengalir di permukaan bumi (run off) dan ada yang meresap ke bawah permukaan bumi (infiltration) (Hadian dan Abdurahman, 2006). Air yang langsung mengalir di permukaan bumi tersebut ada yang mengalir ke sungai, sebagian mengalir ke danau, dan akhirnya kembali ke laut. Sementara itu, air yang meresap ke bawah permukaan bumi melalui dua sistem, yaitu sistem air tidak jenuh (vadous zone) dan sistem air jenuh. Sistem air jenuh adalah air bawah tanah yang terdapat pada suatu lapisan batuan dan berada pada suatu cekungan air tanah. Sistem ini dipengaruhi oleh kondisi geologi, hidrogeologi, dan gaya tektonik, serta struktur bumi yang membentuk cekungan air tanah tersebut. Air ini dapat tersimpan dan mengalir pada lapisan batuan yang kita kenal dengan akuifer (aquifer) (Hadian dan Abdurahman, 2006).

Air tanah tersimpan dalam suatu wadah (akuifer), yaitu formasi geologi yang jenuh air yang mempunyai kemampuan untuk menyimpan dan meloloskan air dalam jumlah cukup dan ekonomis. Formasi geologi dapat dieksplorasi dengan menggunakan metode geofisika, metode geolistrik tahanan jenis dapat digunakan untuk memetakan perlapisan tanah. As'ari (2009), memetakan perlapisan tanah di kompleks Candi Prambanan dan sekitarnya dengan metode geolistrik tahanan jenis konfigurasi Schlumberger. Zubaidah dan Kanata (2008) melakukan penelitian pemodelan físika aplikasi metode geolistrik konfigurasi Schlumberger untuk investigasi keberadaan air tanah. Pemodelan dilakukan pada suatu bak kaca yang diisi dengan pasir dan tanah liat sebagai host-rock dengan injeksi air tanah untuk berbagai volum. Hasil inversi 2-D menggunakan perangkat-lunak IP2WIN menunjukkan bahwa metode geolistrik konfigurasi schlumberger dapat digunakan untuk mengetahui migrasi air tanah.

Kebutuhan air bersih yang bersumber dari air bawah tanah di daerah tertentu meningkat dari tahun ke tahun seiring dengan pertumbuhan penduduk dan kegiatan pembangunan (Hidayat, 2007). Untuk melayani kebutuhan air bersih yang bersumber dari air tanah tersebut, perlu diketahui potensi air tanah baik secara kuantitas maupun kualitas. Seiring dengan bertambahnya penduduk, kebutuhan akan air semakin meningkat baik untuk keperluan kehidupan sehari-hari manusia, peternakan maupun pertanian. Masalah ini memerlukan pemecahan berupa pencarian sumber-sumber air untuk memenuhi kebutuhan tersebut.

Keberadaan air tanah di sekitar Candi Prambanan Kabupaten Sleman Daerah Istimewa
Yogyakarta tidak dapat dijamin ketersediaannya, sehingga perlu dilakukan monitoring lapisan akuifer air tanah. Yang bertujuan memetakan keberadaan akuifer air tanah di daerah tersebut, yang bermanfaat Sebagai dasar acuan bagi pemerintah daerah dalam rangka pengembangan wilayah dan pengolahan sumber daya air tanah untuk kebutuhan masyarakat yang ada di sekitar daerah Candi Prambanan

\section{Metode}

\subsection{Alat dan Bahan}

Alat yang digunakan dalam penelitian ini adalah komputer (Software IP2WIN dan Software Surfer 8). Bahan yang digunakan dalam penelitian ini adalah data eksplorasi dengan menggunakan metode geolistrik yang dilakukan oleh As'ari tahun 2009 dalam penelitian Pemetaan Paleo - Morphology Abad VIII di Kompleks Candi Prambanan dengan Menggunakan Metode Geolistrik.

\subsection{Gambaran Geografi Obyek Penelitian}

Eksplorasi geofisika metode geolistrik konfigurasi Schlumberger dilakukan oleh As'ari tahun 2009, penelitian dilakukan di Kecamatan Kalasan dan Kecamatan Prambanan yang dipisahkan oleh Sungai Opak, tepatnya di Desa Taman Martani (Kecamatan Kalasan) disebelah barat Sungai Opak dan Desa Tlogo, Desa Bugisan dan Desa Taji di sebelah timur Sungai Opak. Secara geografis lokasi penelitian terletak pada 7044'21,3" - 7045'17,4" LS (855506,5 - 857228,1 (UTM)) dan 110028'35,4" 110030'19,6" BT (442274,7 - 445467,6) (UTM)) . Luas daerah penelitian adalah $5.496 .633 \mathrm{~m}^{2}$ atau $5,5 \mathrm{~km}^{2}$.

Penelitian dilakukan pada 31 titik pengamatan yang terbagi menjadi 6 lintasan. lintasan 1 dimulai dari lintasan paling utara sampai lintasan 6 yang paling selatan (Gambar 1). Lintasan 1 terdiri dari 7 titik sounding, yaitu:1, 2, 3, 4, 5, 6 dan 7, lintasan 2 terdiri dari 6 titik sounding, yaitu: 8, 9, 10, 11, 12 dan 13, lintasan 3 terdiri dari 5 titik sounding, yaitu:14, 15, 16, 17 dan 18, lintasan 4 terdiri dari 5 titik sounding, yaitu: 19, 20, 21, 22 dan 23, lintasan 5 terdiri dari 4 titik sounding, yaitu:24, 25, 26 dan 27 , lintasan 6 terdiri dari 4 titik sounding, yaitu: 28,29 , 30 dan 31. Penelitian dimulai tanggal 29 Januari 2009 sampai 14 Pebruari 2009. Kondisi cuaca saat penelitian bervariasi dari cuaca cerah sampai hujan.

\subsection{Perhitungan Data}

Data yang input dalam software IP2WIN berupa nilai jarak elektroda arus ( $\mathrm{c}_{1}$ dan $\mathrm{c}_{2}$ ) dan jarak elektroda potensial ( $p_{1}$ dan $p_{2}$ ) serta nilai resistivitas. Nilai resistivitas diperoleh dengan menggunakan persamaan

$$
\rho=k \frac{\Delta V}{I}
$$

Data Arus (I) adalah nilai masukan yang diinput ke resistivitymeter, beda potensial $(\Delta \mathrm{V})$ adalah nilai yang terbaca sebagai hasil ukur dari resistivitymeter. 
$\mathrm{k}$ adalah Faktor geometri untuk Schlumberger. Hasil hitungan kemudian dikonversi. Konversi untuk setiap jarak elektroda arus yang sama sebenarnya nilai resistivitas semunya adalah sama.

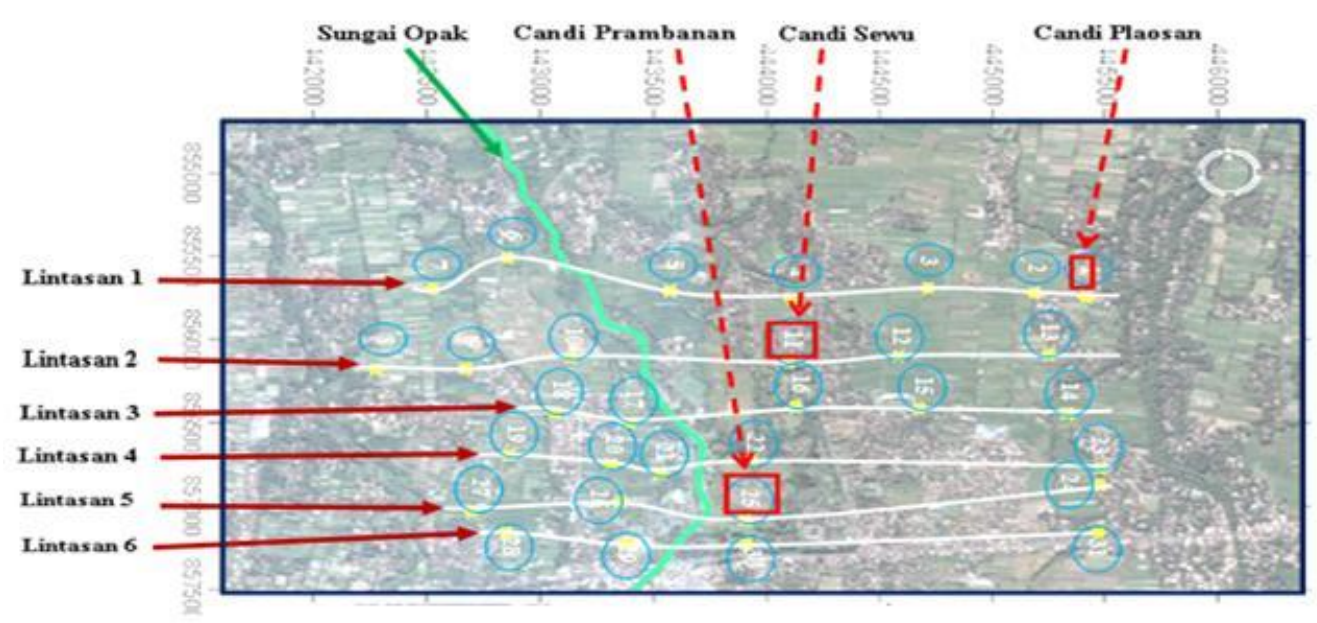

Gambar 1 - Desain Survei Daerah Penelitian (As'ari, 2009).

\subsection{Pengolahan Data Dengan Software IP2WIN}

Software IP2WIN adalah sebuah sarana yang dapat menghasilkan model struktur di bawah permukaan bumi dalam bentuk citra perlapisan berwarna. Citra perlapisan berwarna diinterpretasikan sebagai gambaran model perlapisan dibawah permukaan bumi.

Pengolahan data dengan software IP2WIN yaitu dengan melakukan empat proses pengolahan data. Proses pertama yaitu menentukan nilai faktor geometri dan resistivitas dengan memasukkan panjang jarak spasi elektroda, arus yang diinjeksi, serta beda potensial yang dihasilkan. Sehingga akan muncul plot jarak spasi elektroda dan nilai resistivitas semu, plot data ini membentuk kurva data, di dalam software terdapat pula kurva standar, sebagai panduan dalam melakukan inversi data-data hasil pengukuran. Proses kedua yaitu dengan mencocokkan kedua kurva tersebut, dan menghasilkan informasi berupa nilai resistivitas sebenarnya $(\rho)$, jumlah lapisan batuan $(N)$, ketebalan lapisan (h), dan kedalaman lapisan (d) serta nilai error yang kecil, nilai error tersebut merupakan acuan bahwa pemodelan lapisan batuan yang terukur di bawah permukaan adalah mendekati kebenaran atau tidak. Proses ketiga software membuat tampang lintang (cross-section) terhadap titik-titik sounding yang berada dalam satu lintasan, dengan memasukkan hasil pengolahan sebelumnya diperoleh tampang lintang berupa citra-citra warna yang mewakili nilai resistivitas dari formasi pelapisan bawah permukaan (Huda, 2011).

\subsection{Pengolahan Data Dengan Surfer 8}

Data koordinat ( lintang dan bujur ) setiap titik sounding dan data kedalaman dari hasil pengolahan dengan software IP2WIN kemudian diolah dengan software surfer 8 untuk mendapatkan gambaran peta tiga dimensi. Gambar peta tiga dimensi ini akan menunjukan kedalaman lapisan akuifer air tanah pada masing-masing titik sounding di Kecamatan Prambanan dan Kalasan Kabupaten Sleman Daerah Istimewa Yogyakarta.

\section{Hasil dan Pembahasan}

\subsection{Pengolahan IP2WIN Pada Lintasan Pertama}

Citra berwarna hasil olahan dengan menggunakan software IP2WIN ini diinterpretasikan dengan menggunakan informasi geologi dari data bor yang berasal dari penelitian Hanazato et al., tahun 2007 dalam As'ari 2009, dimana terdapat 3 buah data bor di daerah sekitar Candi Prambanan. Berdasarkan data bor tersebut dapat dijelaskan bahwa geologi daerah penelitian ini terdiri dari tuf Tersier, napal dan andesit, silt Quarternary stratum, tuffaceous clay dan tuff bed.

Lapisan tanah dari permukaan sampai kedalaman $30 \mathrm{~m}$ terdiri dari terutama pasir halus dan lanau, dengan beberapa lapisan mengandung partikel pasir yang lebih besar dan lempungan. Hal ini kemudian diinterpretasi dengan mengasumsikan bahwa secara struktural lapisan tanah di bawah permukaan bumi pada keseluruhan titik sounding di Kecamatan Prambanan dan Kecamatan Kalasan mempunyai kemiripan. Hasil interpretasi data dan informasi geologi ini dapat kita tentukan titik-titik sounding yang memiliki lapisan akuifer berdasarkan nilai resistivitas terkecil (citra berwarna).

Hasil pengolahan dengan software IP2WIN pada titik sounding 1, 2, 3, 4, 5, 7 dan 6 di gabungkan menjadi sebuah lintasan yaitu lintasan 1. Hasil penggabungan pada lintasan 1 seperti pada Gambar 2.

Gambar 2(a) adalah citra perlapisan berwarna pseudo cross-section (tampang lintang semu), sumbu vertikal mewakili kedalaman $(\mathrm{m})$ dan citra berwarna 
mewakili besarnya resistivitas $(\Omega \mathrm{m})$. Gambar 2(b) adalah grafik hasil pengolahan yang menunjukkan hubungan antara spasi elektroda arus dengan titik pusat $(A B / 2)$ pada sumbu-x (panjang bentangan) dan nilai resistivitas pada sumbu-y. kurva merah merupakan kurva standar, garis hitam dengan titiktitik merupakan kurva hasil pengukuran, dan kurva biru adalah gambaran pelapisan. Gambar 2(c) adalah Tabel hasil pengolahan data software IP2WIN yang menjelaskan nilai resistivitas sebenarnya $(\rho)$, jumlah lapisan batuan $(\mathrm{N})$, ketebalan lapisan (h), dan kedalaman lapisan (d).

Gambar 1 merupakan hasil pengolahan data dengan software IP2WIN pada lintasan 1. Daerah yang diduga memiliki akuifer air tanah dangkal adalah pada titik 7 dengan kedalaman 1 - 5 meter (citra warna hitam). Dibawah lapisan ini merupakan lapisan kedap air (citra warna kuning) sehingga air tanah tertahan diatasnya. Pada titik sounding 5 bukan merupakan lapisan akuifer air tanah dangkal hal ini disebabkan pengambilan data dilakukan pada saat hujan, sehingga diperkirakan air tanah pada titik sounding 5 hanya merupakan air genangan hujan. Rembesan air tanah terlihat sampai pada kedalaman 100 meter (citra warna biru dan hitam) yang memiliki nilai resistivitas rendah antara 54.4 - $62.2 \Omega \mathrm{m}$, rembesan air berasal dari titik sounding 2 dan 3, dan diperkirakan dibawah titik sounding ini tidak memiliki lapisan kedap air sehingga air tidak tertahan pada lapisan dangkal. Air merembes dan tertahan dilapisan dalam pada titik sounding $2,3,4$, dan 5 . Untuk titik sounding 1 terlihat rembesan air tertahan pada kedalaman 25 - 50 meter (citra warna hijau) dengan nilai resistivitas $81,6 \Omega \mathrm{m}$, air ini diperkirakan sedang bermigrasi menuju akuifer air tanah dalam.

\subsection{Pengolahan IP2WIN Pada Lintasan Kedua}

Hasil pengolahan dengan software IP2WIN pada titik sounding $8,9,10,11,12$ dan 13 di gabungkan menjadi 1 lintasan yaitu lintasan 2. Hasil penggabungan pada lintasan 2 seperti pada Gambar 3.
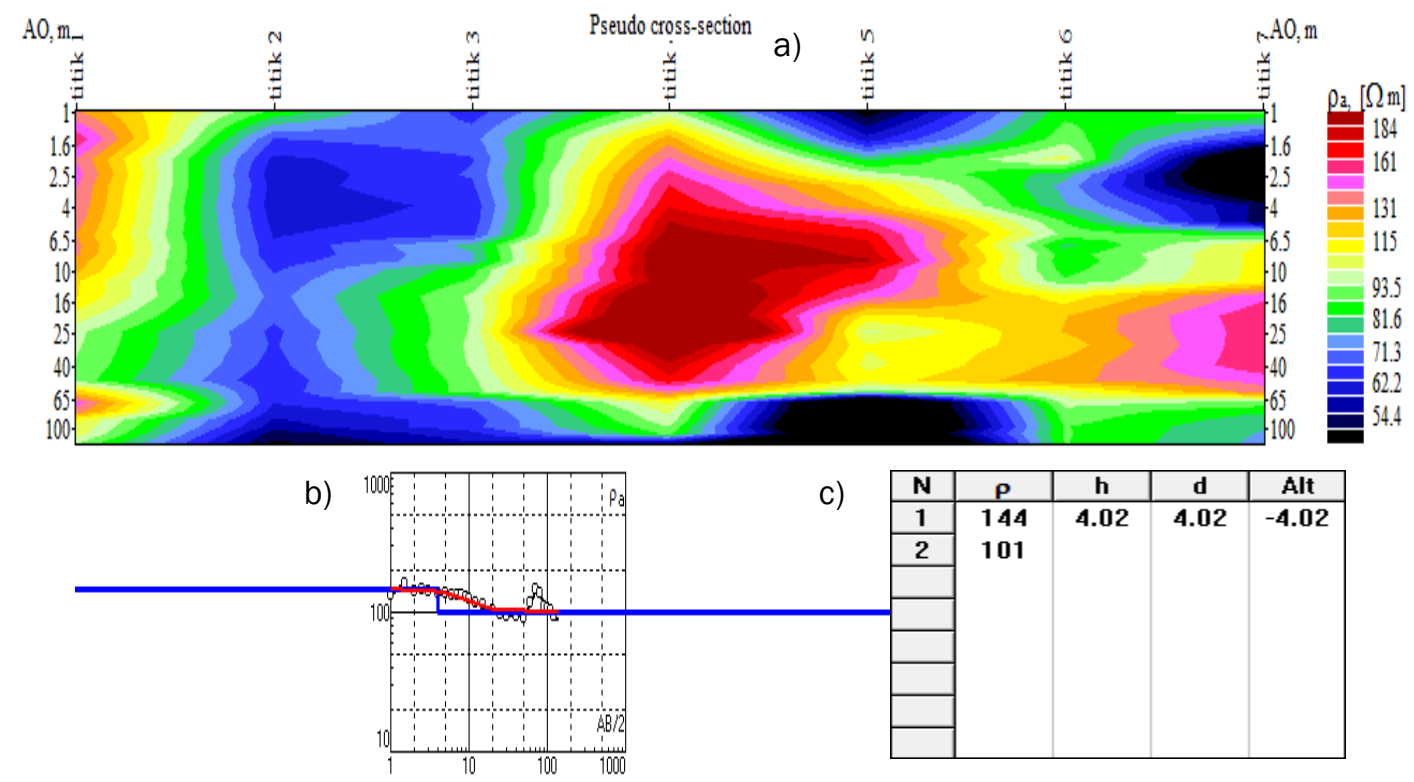

Gambar 2 - pengolahan IP2WIN di lintasan 1 terdiri dari titik sounding 1, 2, 3, 4, 5, 6 dan 7.

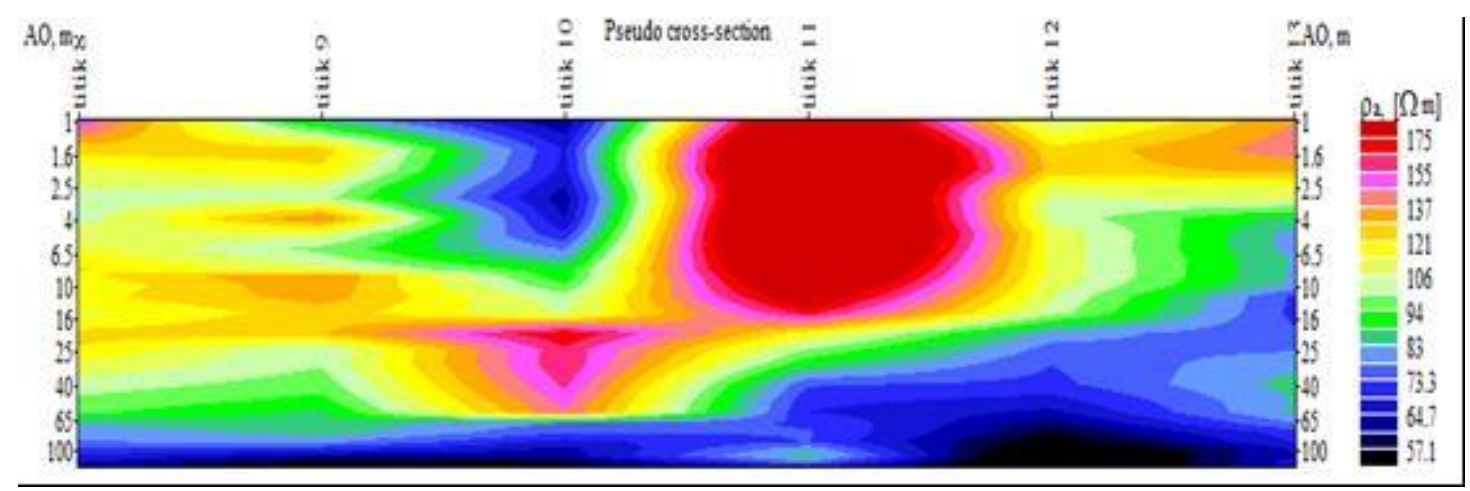

Gambar 3 - pengolahan IP2WIN di lintasan 1 terdiri dari titik sounding 8, 9, 10, 11, 12, dan 13.

Gambar 3 merupakan hasil pengolahan data software IP2WIN pada lintasan 2. Daerah pada lintasan kedua ini tidak ditemukan adanya lapisan yang berpotensi sebagai akuifer air tanah dangkal. 
Citra warna biru dibawah titik sounding 10 yang memiliki nilai resistivitas 64.7 - $73.3 \Omega \mathrm{m}$, kandungan air pada lapisan ini diperkirakan berasal dari resapan air sungai dan air sawah. Air agak tertahan dikarenakan terdapat lapisan yang sedikit berpori (citra warna kuning dengan resistivitas $121 \Omega \mathrm{m}$ pada kedalaman 10 meter). Tetapi air pada akhirnya akan tetap meresap ke lapisan yang lebih dalam. Hal ini terlihat pada lapisan dengan citra warna hitam sebagai lapisan akuifer air tanah yang berada pada lapisan dibawah titik sounding 8, 9, 10, 12.
Sedangkan untuk lapisan 11 dan 13 merupakan daerah yang kering karena tidak memiliki lapisan akuifer air tanah (citra warna orange dan merah).

\subsection{Pengolahan IP2WIN Pada Lintasan Ketiga}

Hasil pengolahan dengan software IP2WIN pada titik sounding $14,15,16,17$, dan 18 di gabungkan menjadi 1 lintasan yaitu lintasan 3. Hasil penggabungan pada lintasan 3 seperti pada Gambar 4.

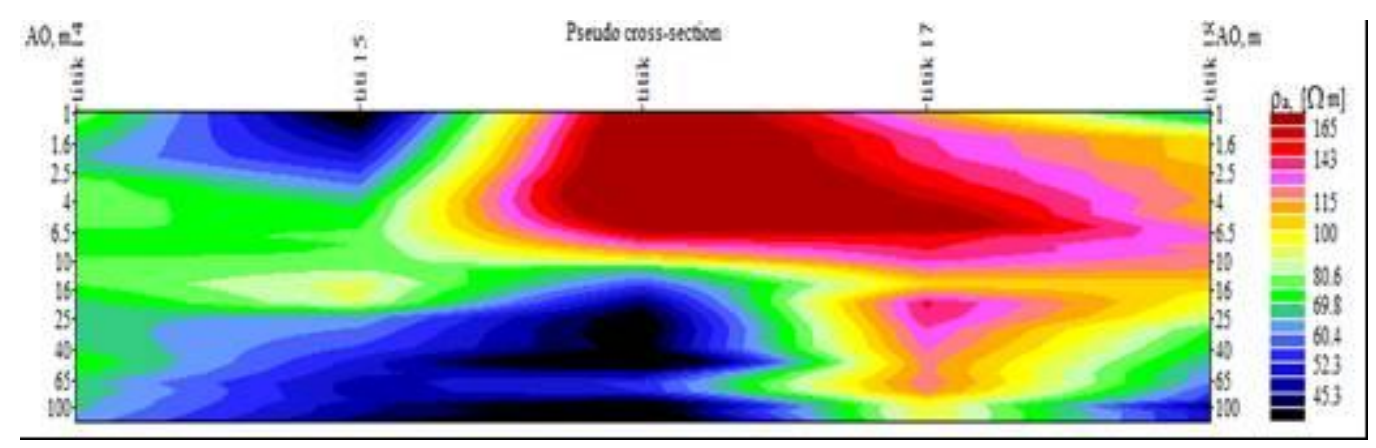

Gambar 4 - Hasil pengolahan IP2WIN di lintasan 3 terdiri dari titik sounding 14, 15, 16, 17, dan 18.

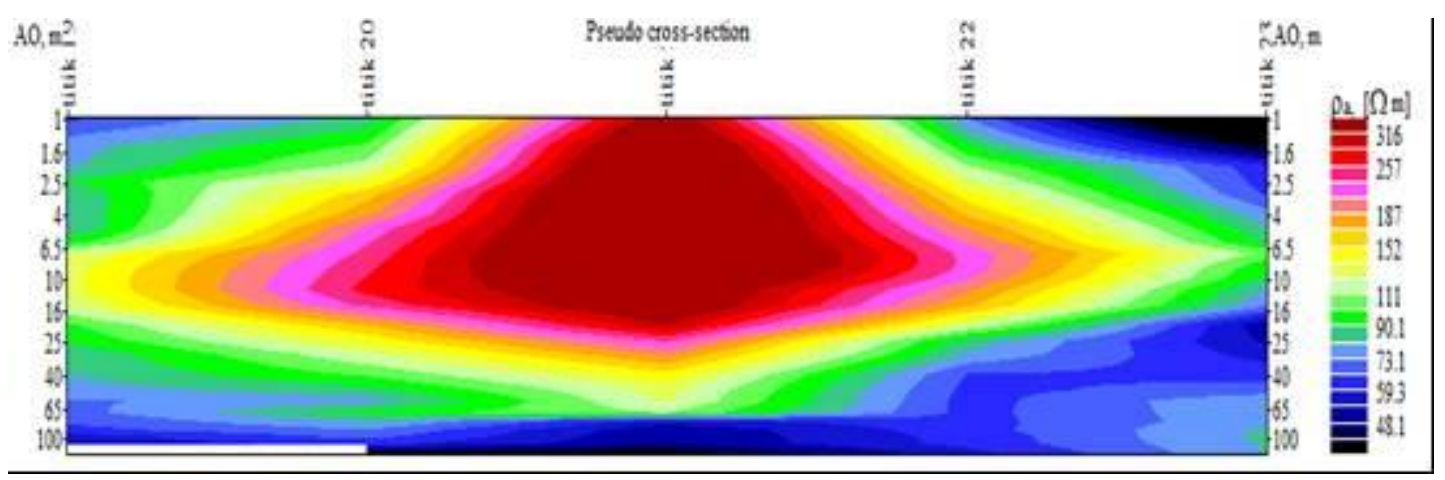

Gambar 5 - Hasil pengolahan IP2WIN di lintasan 4 terdiri dari titik sounding 19, 20, 21, 22 dan 23.

Pada Gambar 4 merupakan hasil pengolahan data dengan software IP2WIN pada lintasan 3. Daerah yang diduga memiliki akuifer air tanah dangkal adalah titik sounding 15 dengan kedalaman 1 - 3 meter (citra warna hitam) dan titik sounding 14 (citra warna biru). Pengambilan data di titik sounding 15 diambil saat hujan, hal ini memungkinkan adanya migrasi air tanah, hal ini juga terlihat pada lapisan dibawahnya (citra warna hijau) dengan nilai resistivitas $69,8 \Omega \mathrm{m}$ merupakan lapisan yang berpori sehingga mampu meloloskan air tanah yang melewatinya. Oleh karena itu rembesan air tanah terjadi hingga kedalaman 60 - 100 meter, hal ini terlihat pada lapisan dengan nilai resistivitas yang rendah pada kedalaman 60 meter dibawah titik sounding 16 (citra warna hitam) dan kedalaman 100 meter dititik sounding 18 (citra warna biru) dan titik sounding 17 (citra warna kuning).

\subsection{Pengolahan IP2WIN Pada Lintasan Keempat}

Hasil pengolahan dengan software IP2WIN pada titik sounding 19, 20, 21, 22 dan 23 digabungkan menjadi 1 lintasan yaitu lintasan 4. Hasil penggabungan pada lintasan 4 seperti pada Gambar 5.

Gambar 5 merupakan hasil pengolahan data dengan software IP2WIN pada lintasan 4. Daerah yang diduga memiliki akuifer air tanah dangkal adalah pada titik 23 dengan kedalaman 1 - 2 meter (citra warna hitam). Di bawah lapisan ini adalah lapisan berpori (citra warna hijau) dengan nilai resistivitas $90,1 \Omega \mathrm{m}$ sehingga air tanah dapat merembes ke bawah sampai pada lapisan dalam, hal ini terlihat pada lapisan dengan citra warna hitam yang diduga sebagai lapisan akuifer air tanah pada kedalaman 100 meter dititik sounding 19, 20, dan 21 sedangkan untuk lapisan 22 tidak terdapat lapisan yang berpotensi sebagai akuifer air tanah. 


\subsection{Pengolahan IP2WIN Pada Lintasan Kelima \\ Hasil pengolahan dengan software IP2WIN pada titik sounding $24,25,26$, dan 27 di gabungkan \\ menjadi 1 lintasan yaitu lintasan 5. Hasil penggabungan pada lintasan 5 seperti pada Gambar 6.}

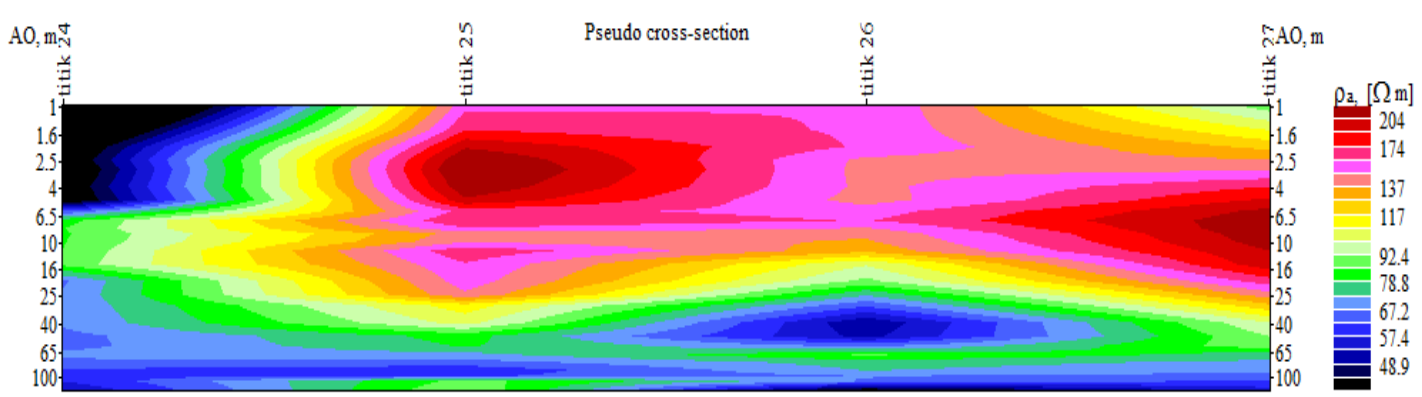

Gambar 6 - Hasil pengolahan IP2WIN di lintasan 5 terdiri dari titik sounding 24, 25, 26, dan 27.

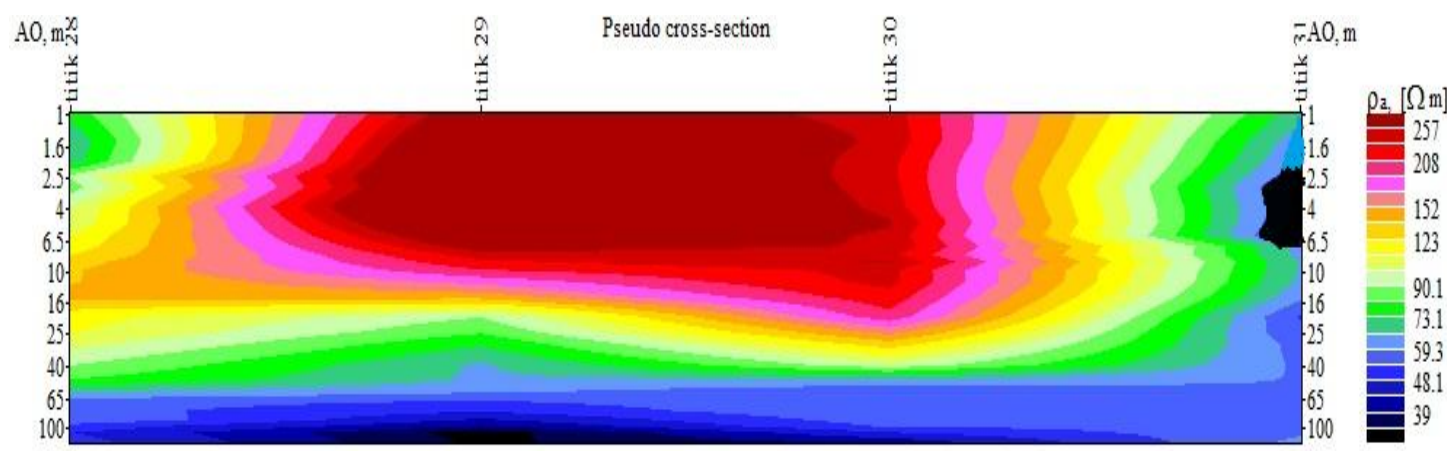

Gambar 7 - Hasil pengolahan IP2WIN di lintasan 6 terdiri dari titik sounding 28, 29, 30, dan 31.

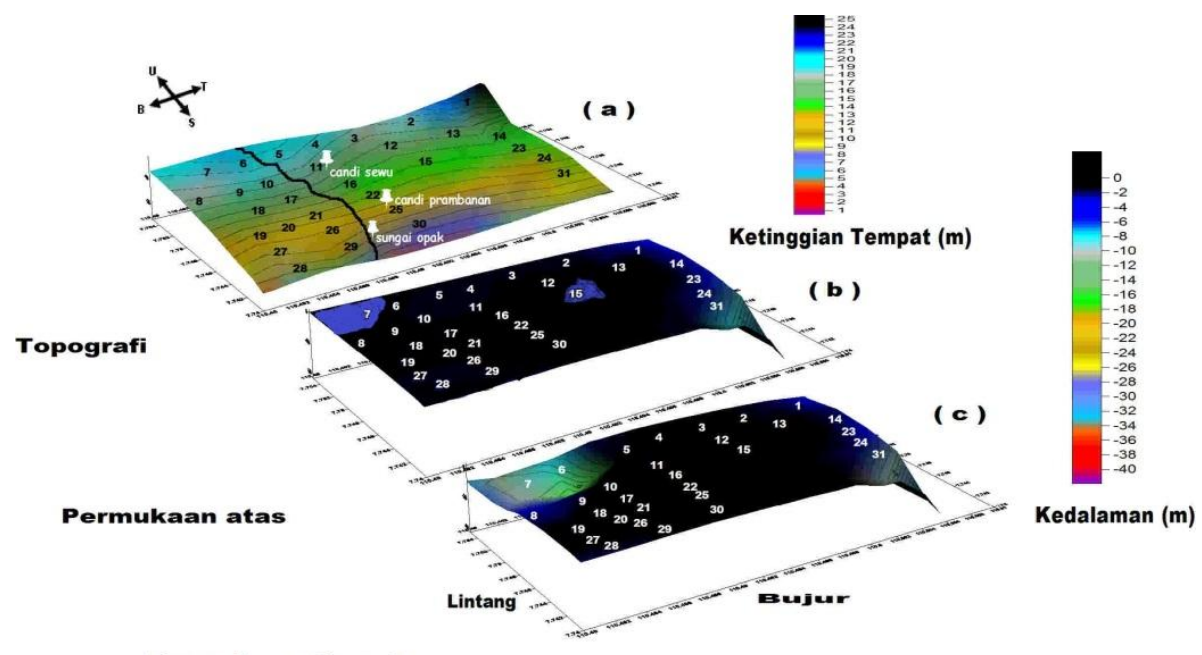

Permukaan Bawah

Gambar 8 - Peta tiga dimensi lapisan akuifer air tanah dangkal (a) Topografi daerah penelitian, (b) Akuifer air tanah dangkal permukaan atas, (c) Akuifer air tanah dangkal permukaan bawah

Gambar 6 merupakan hasil pengolahan data dengan software IP2WIN pada lintasan 5. Daerah yang diduga memiliki akuifer air tanah dangkal dengan lapisan yang memiliki citra warna hitam adalah pada titik 24 dengan kedalaman 1 - 5 meter. Data dititik 24 diambil pada saat cuaca hujan, dan diperkirakan adanya migrasi air tanah menuju lapisan dibawahnya, hal ini diperkuat dengan adanya lapisan berpori dibawahnya (citra warna hijau). Oleh karena itu diduga air tanah merembes dari titik 24 menuju lapisan dalam. Peresapan air tanah terlihat hingga kedalaman 50 - 100 meter (citra warna biru) dititik sounding 25, 26 dan 27.

\subsection{Pengolahan IP2WIN Pada Lintasan Keenam}

Hasil pengolahan dengan software IP2WIN pada titik sounding 28, 29, 30, dan 31 di gabungkan menjadi 1 lintasan yaitu lintasan 6. Hasil 
penggabungan pada lintasan 6 seperti pada Gambar 7.

Gambar 7 merupakan hasil pengolahan data dengan software IP2WIN pada lintasan 6. Daerah yang diduga memiliki akuifer air tanah dangkal adalah pada titik 31 dengan kedalaman 2 - 6,5 meter (citra warna hitam). Lapisan dibawahnya merupakan lapisan berpori (citra wanra hijau) dengan nilai resistivitas $73,1 \Omega \mathrm{m}$, sehingga air tanah dapat meresap melewatinya. Resapan air tanah hingga pada lapisan dalam, hal ini terlihat pada lapisan dengan citra warna hitam sebagai lapisan akuifer air tanah yang berada pada kedalaman 100 meter dititik sounding 29 dan citra warna biru dibawah titik sounding 28 dan 30 .

\subsection{Susunan Kontur Resistivitas Lapisan Akuifer Dangkal Permukaan Dan Dangkal Dalam}

Susunan kontur resistivitas berdasarkan kedalaman lapisan akuifer air tanah dangkal permukaan dan dangkal dalam keseluruhan titik sounding hasil pengolahan dengan software surfer 8 terlihat seperti pada Gambar 8.

Gambar 8 terlihat susunan resisitivitas berdasarkan kedalaman akuifer air tanah dangkal permukaan atas dan permukaan bawah ( 1 - 20 meter ) keseluruhan titik sounding yang ada di Kecamatan Prambanan dan Kalasan Kabupaten Sleman Daerah Istimewa Yogyakarta. Hasil pengolahan data berupa gambar ini didapat berdasarkan letak titik koordinat ( lintang dan bujur ) setiap titik sounding serta data hasil kedalaman sesuai nilai setiap lapisan resistivitas masing-masing titik sounding yang telah diolah dengan software IP2WIN sebelumnya. Berdasarkan gambar 4.13 dapat terlihat susunan kontur resistivitas mulai dari lapisan akuifer air tanah dangkal permukaan atas dan lapisan akuifer air tanah dangkal permukaan bawah. masingmasing lapisan menunjukan secara jelas nilai resistivitas batuan yang ada dimasing-masing titik sounding. Gambar susunan kontur resisitivitas ini menjelaskan secara langsung posisi akuifer air tanah dangkal permukaan dan dangkal dalam daerah penelitian. Setiap titik yang memiliki lapisan akuifer air tanah dangkal diwakili oleh warna biru sampai biru muda berdasarkan kedalaman yang terlihat pada skala warna kontur, sedangkan titik-titik yang tidak memiliki akuifer air tanah dangkal diwakili oleh warna hitam. Berdasarkan pemetaan terlihat titik sounding $7,14,15,23,24$, dan 31 adalah titik-titk sounding yang memiliki lapisan akuifer air tanah dangkal antara 1- 5 meter dengan skala warna biru. Titik 2, 3, $4,5,6,8,9,10,11,12,13,16,17,18,19,20,21$, $22,25,26,27,28,29$, dan 30 berada pada skala warna hitam, artinya titik-titik sounding ini tidak memiliki lapisan akuifer air tanah dangkal.

\subsection{Susunan Kontur Resistivitas Lapisan Akuifer Dalam}

Susunan kontur resistivitas berdasarkan kedalaman lapisan akuifer air tanah dalam keseluruhan titik sounding hasil pengolahan dengan software surfer 8 terlihat seperti pada Gambar 9.

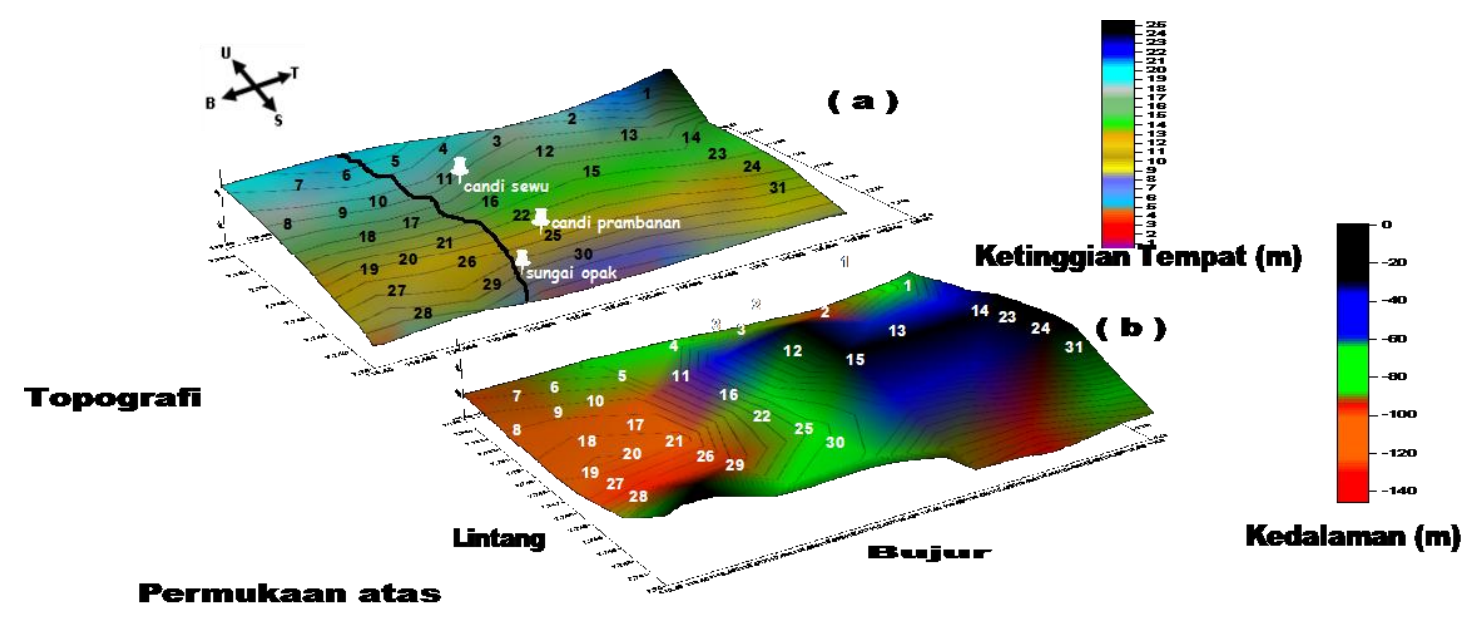

Gambar 9 - Peta tiga dimensi lapisan akuifer air tanah dalam (a) Topografi daerah penelitian, (b) Lapisan akuifer air tanah dalam permukaan atas.

Pada Gambar 9 terlihat susunan resisitivitas berdasarkan kedalaman akuifer air tanah dalam ( 25 100 meter ) keseluruhan titik sounding yang ada di Kecamatan Prambanan dan Kalasan Kabupaten Sleman Daerah Istimewa Yogyakarta. Hasil pengolahan data berupa gambar ini diperoleh dengan input berupa letak titik koordinat ( lintang dan bujur ) setiap titik sounding dan data hasil kedalaman akuiefr air tanah dalam masing-masing titik sounding hasil olahan software IP2WIN sebelumnya. Gambaran susunan kontur resisitivitas ini menjelaskan secara langsung posisi akuifer air tanah dalam permukaan atas daerah penelitian. Setiap titik yang memiliki lapisan akuifer air tanah dalam diwakili oleh warna biru, hijau sampai merah berdasarkan kedalaman yang terlihat pada skala warna kontur, sedangkan titik-titik yang tidak memiliki akuifer air tanah dalam diwakili oleh warna hitam. Berdasarkan pemetaan 
terlihat titik sounding 11, 13, 14, 15, 23, 24, dan 31 adalah titik-titk sounding yang tidak memiliki lapisan akuifer air tanah dalam, dengan skala warna hitam. Titik 2, 3, 4, 5, 8, 9, 10, 12, 16, 17, 18, 19, 20, 21, $25,26,27,28,29$, dan 30 berada pada skala warna biru, hijau dan merah, artinya titik-titik sounding ini memiliki lapisan akuifer air tanah dalam dengan kedalaman antara 25 - 100 meter.

Lapisan akuifer air tanah dalam permukaan bawah tidak dapat dipetakan karena keterbatasan kemampuan alat ukur terhadap resistivitimeter yang tidak dapat mengukur resistivitas secara akurat untuk pengukuran yang lebih dalam.

\section{Kesimpulan}

Didapatkan lapisan akuifer air tanah dangkal dengan kedalaman antara (1-5 meter) yang tersebar di Kecamatan Prambanan : Desa Bugisan (titik sounding 7) Desa Taji (titik sounding 14, 15, 23, 24, dan 31). Didapatkan lapisan akuifer air tanah dalam dengan kedalaman (25-100 meter) yang tersebar di Kecamatan Prambanan : Desa Bugisan (titik sounding 1, 2, 3, 4, dan 5), Desa Tlogo (titik sounding 12, 16, dan 25).
Di Kecamatan Kalasan : Desa Taman Martani (titik sounding $8,9,10,17,18,19,20,21,26,27$, 28,29 , dan 30)

\section{Daftar Pustaka}

As'ari. 2009. Pemetaan Paleo-Morphologi Abad VIII di Kompleks Candi Prambanan Menggunakkan Metode Geolistrik. FMIPA UGM. Yogyakarta

Huda, Miftahul. Pemetaan Air Tanah Menggunakan Metode Resistivitas Wenner Sounding. Jurnal Neutrino. 2011

Hidayat, R.S. Penyelidikan Potensi Air Tanah CAT Sambas. Jurnal Geologi. 2007, 61, 205-206.

Zubaidah, T dan B. Kanata. Pemodelan Fisika Aplikasi Metode Geolistrik Konfigursi Schlumberger. Jurnal Teknologi Elektro. 2008, 61, 20-21.

Hadian, M.S.D. dan O. Abdurahman. Sebaran Akuifer dan Aliran Air Tanah di Kecamatan Batuceper dan Kecamatan Benda Kota Tangerang, Provinsi Banten. Jurnal Geologi Indonesia. 2006, 61, 115116. 